<原 著 $>$

シメチジンによる $\mathrm{CCl}_{4}$ 肝障害の抑制とその機序に関する検討

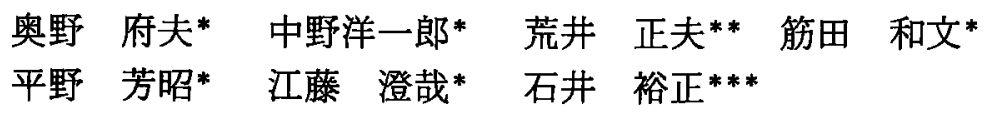

要 旨： $\mathrm{H}_{2}$ ブロッカーのシメチジンをラットに $\mathrm{CCl}_{4}$ 投与 1 時間前に投与することにより生ず

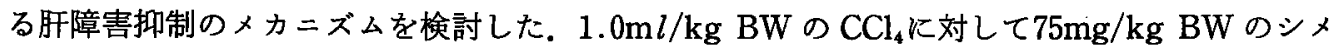
チジン前投与では肝障害抑制作用はなく, $150 \mathrm{mg} / \mathrm{kg} \mathrm{Bw}$ の量を必要とした. $150 \mathrm{mg} / \mathrm{kg}$ BW の シメチシンの前投与によって血清 GOT・GPT 值の上昇は有意他抑制され，組織学的にも脂肪 変性・肝細胞壊死の程度は極めて軽減された。肝チトクロームP-450量は $\mathrm{CCl}_{4}$ により50\%以下 に著減したが、シメチシンンよりその減少は有意に抑制された，血中・肝缄中の過酸化脂質量 (MDA）は $\mathrm{CCl}_{4}$ により著增したが，シメチジンによりその増加が抑制された。肝臟中 GSH 量 は $\mathrm{CCl}_{4}$ ・シメチジン投与によっていずれも変動はみられなかった. $\mathrm{CCl}_{4}$ の肝障害発現には脂質 の過酸化が重要であり，シメチジンはこの過酸化脂質の産生を抑制することによって肝障害を 軽減するものと考克られた。

索引用語：シメチジン 四塩化炭素肝障害 脂質過酸化 チトクロームP-450 グルタチオン

はじめに

シメチジンは $\mathrm{H}_{2}$ レセプター阻害剤として1975年に SKF Laboratory によって合成され，翌年から踟床使 用され，その強力な胃酸分泌抑制作用により消化性潰 湯の治療に著明な効果を発揮してきた。しかし，1978 年 SKF Laboratryに対して,シメチジンと同時に投 与された抗凝固剤ワーフフリンの効果が延長したとい ら報告がなされたため, 同研究所の Flind ${ }^{11}$ はシメチジ ン投与中の患者にワーファリンを併用する場合には凝 固時間を頻回にチェックするなどして充分注意するよ 5に警告を発した。翌1979年 Serlin ら²はシメチシンン とワーファリンを併用すると，プロトロビン時間が延 長し、ワーファリンの血獎クリアランスが低下するこ と，さらにシメチジンと同時に投与されたアンチピリ ンの血䟿クリアランスむ低下することを示し，シメチ ジンが薬物代謝を抑制するためであろうと推測した。

続いて, Rendic $5^{3)}$, Klotz $5^{4)}$, Patwardhan $5^{5)}$ は シメチシンによる薬物代謝抑制の機序として, 肝ミク ロソームの薬物代謝経路 Mixed function oxidase

\footnotetext{
- 産業医科大学第 1 内科

**同 中央臨床桧查部

***度応義熟大学内科
}

＜受付日63年 4 月28日>
(MFO)が関与していることを示した. 即ち, シメチジ ンは肝ミクロソームに存在する $\mathrm{MFO}$ の主な構成成分 のひとつであるチトクロームP-450（P-450）のーム部 分と選択的に結合し，その䣼素活性を阻害すること， 従ってP-450を介する phase I反応のみを阻害し，P. 450を介さない phase II の薬物代謝は阻害しないこと などを報告した。

一方, 四塩化炭素 $\left(\mathrm{CCl}_{4}\right)$ は実験的肝障害作製のモ デル薬物として広く用いられ, 中毒学の研究に寄与し てきた．その肝毒性発生の機序として，CCl ロソームで代謝をらけた際に, 中間代謝産物として free radical である $\mathrm{CCl}_{3}$ が産生され, $\mathrm{CCl}_{3}$ が細胞膜を はじめミトコンドリア膜, ミクロンーム膜などの膜構 成成分である脂肪酸を攻撃し, chain reaction で次々 にラジカルを作って膜を破壊して肝細胞壊死をおこす と考えられている6.

そこで, シメチジンが $\mathrm{CCl}_{4}$ の代謝を阻害することに 上り，反応性代謝産物である $\mathrm{CCl}_{3}$ の生成を抑制し，ひ いては肝障害の発生を軽減するのではないかと推測さ

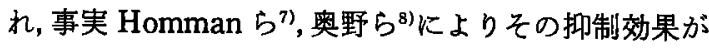
報告されているが，否定的な報告もみられる97. 今回， 著者らは種々の異なった量のシメチジンを $\mathrm{CCl}_{4}$ 投与 1 時間前に投与して肝障害発現への影響を倹討したの 
Table 1 Effective protective dose of cimetidine on $\mathrm{CCl}_{4}$-induced liver injury.

\begin{tabular}{c|cc|cc|cc}
\hline & $\mathrm{CCl}_{4}(5)$ & $\begin{array}{c}75 \mathrm{mg} / \mathrm{kg} \\
\text { of } \\
+ \text { Cimetidine(5) }\end{array}$ & $\mathrm{CCl}_{4}(5)$ & $\begin{array}{c}150 \mathrm{mg} / \mathrm{kg} \\
\text { of } \\
+ \text { +Cimetidine(5) }\end{array}$ & $\mathrm{CCl}_{4}$ (5) & $\begin{array}{c}200 \mathrm{mg} / \mathrm{kg} \\
\text { of } \\
\text { of }\end{array}$ \\
\hline GOT & $2233 \pm 1405$ & $2194 \pm 2138$ & $883 \pm 310$ & $536 \pm 185^{*}$ & $1086 \pm 309$ & $1105 \pm 387$ \\
GPT & $804 \pm 857$ & $568 \pm 599$ & $230 \pm 135$ & $80 \pm 34^{* *}$ & $386 \pm 269$ & $402 \pm 191$ \\
\hline
\end{tabular}

" $\mathrm{p}<0.02$ when compared to respective control. ${ }^{* *} p<0.05$ when compared to respective control.

で報告する，

\section{方 法}

体重約200g の Wistar 系雄性ラットを用いた, $\mathrm{CCl}_{4}$ は corn oil に 1 対 1 に焀かしたものを用い，対照とし て純 corn oil を用いて腹腔内投与した。 シメチジン末 $0.675 \mathrm{~g}$ を $1 \mathrm{~N} \mathrm{HCl} 3.3 \mathrm{~m} l, 0.1 \mathrm{~N} \mathrm{NaOH} 6.0 \mathrm{~m} l$ に溶解 し, 最終濃度 $22.5 \mathrm{mg} / \mathrm{ml}(\mathrm{pH} 6.0)$ として使用した。

1. 有効シメチシン量の決定

$\mathrm{CCl}_{4}$ 投与量を $1.0 \mathrm{ml} / \mathrm{kg} \mathrm{BW}$ とてて有効シメチシン 量を検討した。即ち $\mathrm{CCl}_{4}$ 投与 1 時間前にシメチシン $75,150,200 \mathrm{mg} / \mathrm{kg} \mathrm{BW}$ を腹腔内投与し，18時間後に 血液生化学的に血將 GOT・GPT 活性を測定した。表 1 に示すよらに $75 \mathrm{mg} / \mathrm{kg} \mathrm{BW}$ のシメチシンでは $\mathrm{CCl}_{4}$ 肝障害を抑制しなかったが，150mg/kg BWでは GOT·GPT 活性の上昇を有意に抑制した。しかし, 200 $\mathrm{mg} / \mathrm{kg} \mathrm{BW}$ に増量してもそれ以上の抑制効果は認め られなかった。従って以下の実験には $150 \mathrm{mg} / \mathrm{kg} \mathrm{BW}$ のシメチシンン量を使用した。

2. $\mathrm{CCl}_{4}$ 投与肝代謝能に及ぽすシメチシンの影響

上述したよらな方法で $\mathrm{CCl}_{4}$ とシメチジンを投与し た。さらに, 各々の群の対照として, $\mathrm{CCl}_{4}$ の代わりに corn oil をシメチジンの代わりに生食をそれぞれ同量 腹空内投与した． $\mathrm{CCl}_{4}$ 投与18時間後に断頭屠殺し，頸 部血管から一ハリンン採血して血液生化学的検査に用い た. 肝は, 門脈から約 $10 \mathrm{~m} l$ の泠生食水で潅流し肝から 血液を洗い流した後， $1.15 \% \mathrm{KCl}$ で25\%ホモジネート

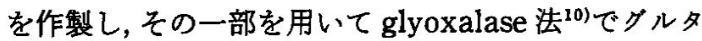
チオン量を測定した. 残ったホモジートは10,000 G20分遠沈し，その pelletをさらに100,000G60分超遠 沈し最終的に $1.15 \% \mathrm{KCl}$ に鬃濁しミクロソーム溶液 とした。ミクロソーム中の malondialdehyde (MDA) を thiobarbituric acid 法11)で，チトクローム $b_{5}\left(b_{5}\right)$ とP-450を Omura \& Sato の方法 ${ }^{12)}$ で測定した。各分 画中の蛋白量を Lowry 法13)で測定した。

また, 潅流前の肝の一部をホルマリン固定後, HE 染 色を施し組織学的検討に供した。

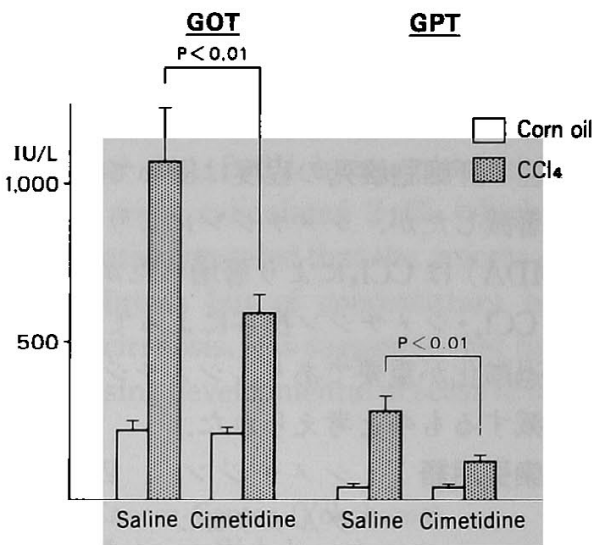

Fig. 1 Effect of cimetidine on serum GOT and GPT activity in $\mathrm{CCl}_{4}$-treated rats.

\section{なおデータはMean士SDで表わした. 結果}

1. 血液生化学的成績

血清 GOT・GPT 值について図 1 k提示した. $\mathrm{CCl}_{4}$ 投与により血清 GOT・GPT 值は著増し，肝障害が薏 起された。しかしこのトランスアミナーゼの上昇は シメチジンの前投与により有意に抑制されたが，なお 生食十corn oil 群に比し高値であった。 シメチシン単 独では血清 GOT・GPT 活性に影響を及ぼさなかっ た.

\section{2. 肝組織学的成績}

$\mathrm{CCl}_{4}$ 単独投与により肝は小葉中心性に肝細胞の壊 死, 肝細胞索の乱れが高度で，小葉中間帯には肝細胞 風船化，脂肪の沈着が著明であった（図 2A）.シメチ シンの前投与により $\mathrm{CCl}_{4}$ による肝の変化は極めて軽 度となり, 細胞索は規則的で, 軽度の壊死と脂肪沈着 にとどまった（図 2B）.シィチジン単独では，光顕的 に肝に異常は認められなかった。

3. 血中及び肝葴中の過酸化脂質

血中 $\mathrm{MDA}$ 量は $\mathrm{CCl}_{4}$ 投与により著明に増加したが， シメチシンを前投与しておくことによりその増加は有 


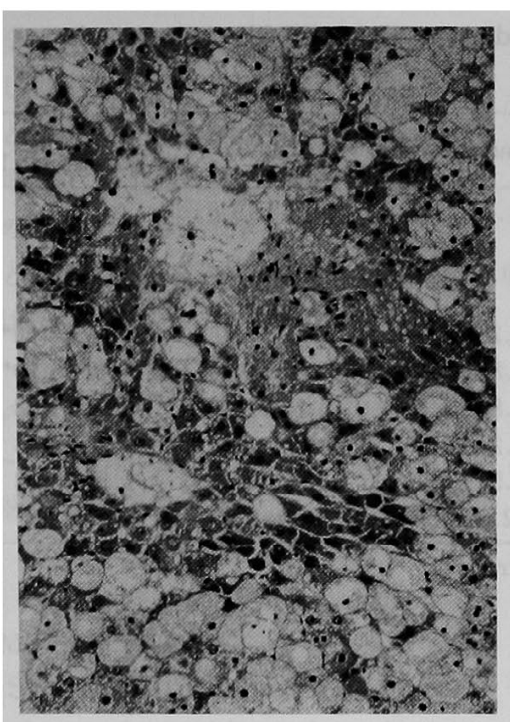

A

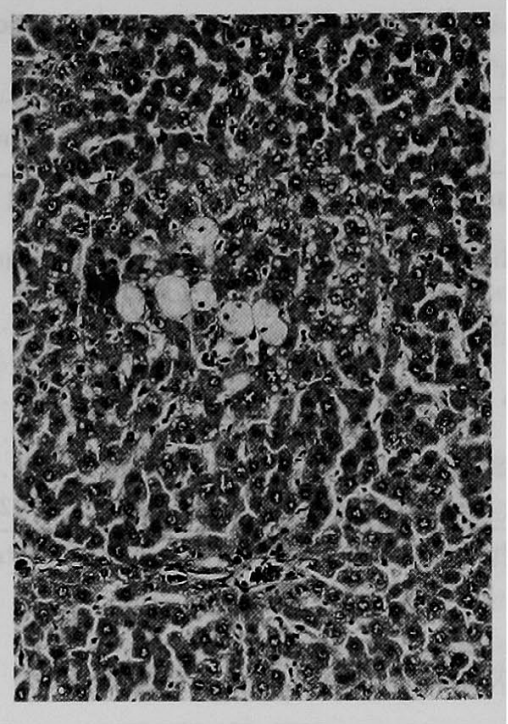

B

Fig. 2 Liver histology of $\mathrm{CCl}_{4}$-treated rats.

A : Liver from $\mathrm{CCl}_{4}$-treated rat. B : Liver from rat pretreated with cimetidine.

Table 2 Effect of cimetidine on MDA contents in blood and liver of $\mathrm{CCl}_{4}$-treated rats.

\begin{tabular}{lcccc}
\hline & Control(4) & Cimetidine(4) & $\mathrm{CCl}_{4}(9)$ & $\begin{array}{c}\mathrm{CCl}_{4} \\
+ \text { Cimetidine(10) }\end{array}$ \\
\hline MDA in blood (nmole/ml) & $6.7 \pm 0.5$ & $5.1 \pm 0.4^{*}$ & $12.7 \pm 0.7$ & $3.5 \pm 0.6^{* *}$ \\
MDA in liver $(\mu \mathrm{mole} / \mathrm{g}$ liuer) & $3.1 \pm 0.7$ & $1.2 \pm 0.1$ & $13.6 \pm 5.2$ & $9.4 \pm 2.9^{* * *}$ \\
\hline
\end{tabular}

${ }^{*} \mathrm{p}<0.05$ when compared to respective controls.

${ }^{* *} \mathrm{p}<0.001$ when compared to respective controls.

$* * * p<0.01$ when compared to respective controls.

意に抑制された（表 2). シメチシン単独投与により， 血中 MDA 量は対照群に比し低値となった. 肝臓中 $\mathrm{MDA}$ 量も対照群 $3.1 \mu \mathrm{mole} / \mathrm{g}$ liverに比し $\mathrm{CCl}_{4}$ 投与 により $13.6 \mu \mathrm{mole} /$ gliver と著增したが, シメチシン 前投与により $9.4 \mu \mathrm{mole} / \mathrm{g}$ liver と MDAの上昇は有 意に抑制された(表 2). シメチシンのみでは肝䁍中の MDA $1.2 \mu \mathrm{mole} / \mathrm{g}$ liver と対照群に比し低值を示 した.

\section{4. 肝薬物代謝系に及ぼす影響（表 3)}

肝ホモシネート蛋白量は肝障害を反映して $\mathrm{CCl}_{4}$ 群 が若干低值を示したが, 有意でなく, 肝ミクロソーム 蛋白量も $\mathrm{CCl}_{4}$ ・シメチシン投与により影響は受けな かった.

P-450は $\mathrm{CCl}_{4}$ に上り50\%以下に著明に低下したが， シメチシン前投与によりその低下は有意に抑制され た.これは，P-450量を単位肝重量当りと単位蛋白量で 表現してす同様であった。 $b_{5}$ 量は各処置によって影響
を受けなかった.

また訮葴中 $\mathrm{GSH}$ 量についても， $\mathrm{CCl}_{4}$ 投与, シメチジ ン前投与によって変化はみられなかった。

考 察

1978年にシメチシンが同時投与薬剂の代謝を抑制す ることが明らかになって以来”臨床的にも動物実験的 にも,シメチシンが肝ミクロンームにおける種々の薬 物の代謝を阻害することが明らかにされた。その阻害 の機構は，肝ミクロンームの薬物代謝系において中心 的役割を果たすチトクロームP-450とシメチシンが結 合することにより，同時投与された薬物の代謝が阻害 されるるのと考光られている ${ }^{3 \sim 5)}$. 事実, ミクロソーム 中にシメチジンを加えると容量依存性に Type II のス ペクトルの変化が抗こることが確かめられてい る3.14). 従って, ミクロソームのP-450系で代謝を受け, その代謝産物が肝毒性を発揮するような薬物の場合 は, シメチシンによって毒性が軽減される16). 逆にP. 
Table 3 Effect of $\mathrm{CCl}_{4}$ and cimetidine on contents of hepatic proteins, cytochromes and GSH.

\begin{tabular}{|c|c|c|c|c|c|}
\hline & & Control(4) & Cimetidine(4) & $\mathrm{CCl}_{4}(9)$ & $+\mathrm{CCl}_{4}$ \\
\hline \multicolumn{2}{|c|}{$\begin{array}{c}\text { Homogenate protein } \\
\mathrm{mg} / \mathrm{g} \text { liver }\end{array}$} & $203.3 \pm 20.5$ & $201.3 \pm 18.7$ & $179.3 \pm 10.8$ & $178.6 \pm 6.9$ \\
\hline \multicolumn{2}{|c|}{$\begin{array}{l}\text { Microsomal protein } \\
\mathrm{mg} / \mathrm{g} \text { liver }\end{array}$} & $18.9 \pm 2.8$ & $20.1 \pm 4.4$ & $18.2 \pm 2.9$ & $19.0 \pm 0.9$ \\
\hline \multirow[t]{2}{*}{ P-450 } & $\mathrm{n} \mathrm{mol} / \mathrm{g}$ liver & $14.76 \pm 2.09$ & $16.20 \pm 3.17$ & $5.81 \pm 2.48$ & $8.56 \pm 2.20^{*}$ \\
\hline & $\mathrm{n} \mathrm{mol} / \mathrm{mg}$ prot. & $0.78 \pm 0.06$ & $0.80 \pm 0.13$ & $0.31 \pm 0.10$ & $0.45 \pm 0.09^{*}$ \\
\hline \multirow[t]{2}{*}{$b_{5}$} & $\mathrm{n} \mathrm{mol} / \mathrm{g}$ liver & $4.48 \pm 1.11$ & $4.84 \pm 1.60$ & $5.20 \pm 1.33$ & $6.25 \pm 1.68$ \\
\hline & $\mathrm{n} \mathrm{mol} / \mathrm{mg}$ prot. & $0.24 \pm 0.36$ & $0.24 \pm 0.66$ & $0.28 \pm 0.04$ & $0.33 \pm 0.08$ \\
\hline \multirow[t]{2}{*}{ GSH } & $\mathrm{mg} / \mathrm{g}$ liver & $2.35 \pm 0.22$ & $2.58 \pm 0.20$ & $1.90 \pm 0.41$ & $1.70 \pm 0.28$ \\
\hline & $\mu \mathrm{g} / \mathrm{mg}$ prot. & $11.6 \pm 0.9$ & $12.9 \pm 0.7$ & $10.7 \pm 2.6$ & $9.6 \pm 1.7$ \\
\hline
\end{tabular}

* $p<0.05$ when compared to respective controls.

450系と無関係に代謝される薬物には影響を及ぼさな (.5).

いくつかある $\mathrm{H}_{2-}$ レセブター拮抗剤のすべてが薬 物代謝を阻害する訳ではないことから，阻害効果はン メチジンの持つイミダゾール環にあり，抗ヒスタミン 作用によるものではないとされている(16). 事実, イミダ ゾール環を有する物質はミクロソームの醉素活性を抑 制することは広く知られている豆しし，フラン環を持つ ラニチシンには薬物代謝抑制作用はそしい。

$\mathrm{CCl}_{4}$ は肝ミクロソームにおいてP-450によって代謝 される際に,トリクロロメチルフリーラジカル $\left(\mathrm{CCl}_{3}{ }^{\circ}\right)$ が産生される.この $\mathrm{CCl}_{3}$ が膜の脂質を過酸化的に攻撃 したり，膜分子と共有結合を招こし不対電子を放出し， 膜脂質からフリーラジカルが chain reation によって 次々に産生され, 膜が傷害され細胞が破壊される6,18). これは $\mathrm{CCl}_{4}$ 投与により脂質の過酸化物すなわち MDA が著增していることからす理解できる.GSH は 中間代謝産物 $\mathrm{CCl}_{3}$ と抱合し無毒化するととすに， GSH peroxidase の存在下でフリーラシ்カルを消去す る. 以上の上5に $\mathrm{CCl}_{4}$ が P-450で代謝されることに よって肝毒性を発揮することから,シメチジンが $\mathrm{CCl}_{4}$ の肝毒性を軽减するであろらことが推測される. 1983 年 Homman $5^{71}$ は $2.5 \mathrm{ml} / \mathrm{kg} \mathrm{CCl}{ }_{4}$ の投与前 150 分，同 時，投与後 150 分に $40 \mathrm{mg} / \mathrm{kg}$ シメチジンを腹腔内投与 乙，血清 GOT の上昇の抑制之組織学的改善をみてい る. Leonard ら9は $2.0 \mathrm{ml} l / \mathrm{kg} \mathrm{CCl}_{4}$ を経口投与し, $\mathrm{CCl}_{4}$ 投与の 30 分前に $41 \mathrm{mg} / \mathrm{kg}$ のシメチシンを経口投与し， 血清 GOT 上昇の抑制をみているが有意ではなかった と報告している。そして抑制効果がみられなかった理 由を、シメチジン投与方法の違いに求めている，奥野
ら ${ }^{8)}$ は $5.0 \mathrm{~m} l / \mathrm{kg}$ の $\mathrm{CCl}_{4}$ 投与前に penobarbital 10 日間前投与し $\mathrm{MFO}$ を誘導しておいて， $\mathrm{CCl}_{4}$ 投与の 1 時間前と 1 時間後にそれぞれ $200 \mathrm{mg} / \mathrm{kg}$ のシメチジン を腹腔内投与して，血清 GOT・GPT 上昇の抑制之組 織学的な改善をみているが, P-450减少の抑制はみられ ていない

著者らの成績によると1）ミクロソームの薬物代謝 系酵素を誘導しなくても，シメチジンの抑制效果がみ られること2）P-450の減少す有意に抑制されること 3） MDA の増加も抑制されることが明らかになった。 特にMDAの上昇が抑制されていることは，シメチジ ンが過酸化脂質の産生を抑制していることを示するの で，従来から述べられているシメチシンの薬物代謝阻 害機構と一致するすのである. シメチジンには P-450 量を増減する作用はなく，前投与期間を長くしても $\mathrm{CCl}_{4}$ 肝障害抑制効果に变わりはなかった（未発表デー タ).これる，シメチジンがリガンドとしてP-450分子 に結合することによって MFO を阻害するといら考皇 を支持する所見である。著者らの成績に反して, Cluet ら ${ }^{199}$ はシメチシンは $\mathrm{CCl}_{4}$ の脂質過酸化を抑制しな かったと述べている．しかし，彼らのデータをよく検 討すると， $\mathrm{CCl}_{4}$ 投与によって $\mathrm{MDA}$ の増加がみられて いない.これは $\mathrm{CCl}_{4}$ 投与後わずか 4 時間後に屠殺され ており， $\mathrm{CCl}_{4}$ 肝毒性は投与12２4時間にピークに達す るといわれているので18)，未だMDAの上昇がみられ る前に屠殺されている可能性すある。また，彼らはシ メチジンによって $\mathrm{CCl}_{4}$ 肝障害が軽減されたか否か言 及していない，

今回の著者らの研究を含めて, シメチジンの $\mathrm{CCl}_{4}$ 肝 毒性㧕制効果を認めた報告7ー9)は 3 つあるが, いずれも 
その抑制効果は完全ではない，不完全な抑制効果しか 得られない理由として,シメチシンン投与量が $\mathrm{CCl}_{4}$ 投与 量に比し少ないことが考えられるが，シメチジン投与 量を $200 \mathrm{mg} / \mathrm{kg}$ に増量しても抑制効果は增強されな かったことからこの可能性は否定できよう. $\mathrm{CCl}_{4}$ の肝 毒性発現機構のひとつとして, 脂質過酸化作用以外に $\mathrm{CCl}_{4}$ 自身の脂質溶解作用 ${ }^{18)}$ 中との他の機構文考元ら れる. 即ら、フリーラジカル消去剤で MDA の産生を 抑制しても肝障害の発現は抑制できなかったといら報 告10)すり, フリーラジカル以外の機序が関与してい る可能性もあり今後の研究課題である.

\section{文献}

1) Flind AC: Cimetidine and oral anticoagulants. Br Med J ii : 1367, 1978

2) Serlin MJ, Sibeon RG, Mossman $S$, et al : Cimetidine: Interaction with oral anticoagulants in man. Lancet ii : $317-319,1979$

3) Rendic S, Sunjic R, Toso R, et al : Interaction of cimetidine with liver microsomes. Xenobiotica 9: 555-564, 1979

4) Klotz U, Reimann I: Influence of cimetidine on the pharmacokinetics of desmethyldiazepam and oxazepam. Eur J Clin Pharmacol, 18: 517 $-520,1980$

5) Patwardhan RV, Yarborough GW, Desmond $\mathrm{PV}$, et al : Cimetidine spares the glucuronidation of lorazepam and oxazepan. Gastroenterology 79 : 912-916, 1980

6) Recknagel RO: Carbon tetrachloride hepatotoxicity. Pharmacol Rev 19 : 145-208, 1967

7) Homman J, Schneider S, Rotter $S$, et al: Cimetidine reduziert durch $\mathrm{CCl}_{4}$ hervorgerufene Leberschäden. Z Gastroenterol 8: 461-462, 1983

8）奥野裕康, 村瀬登志彦, 羽間 弘, 他：実験肝障害 に及ぼす cimetidine の影響-acetaminophen, $\mathrm{CCl}_{4}$, galactosamine 肝障害を比較して一, 肝臓 $28: 154-163,1987$

9) Leonard TB, Dent JG: Effect of $\mathrm{H}_{2}$ receptor antagonists on the hepatotoxicity of various chemicals. Res Commun Chem Pathol Pharmacol 44 : 375-388, 1984

10) Bernt E, Bergmeyer HV: Glutathione. In :
Methods of enzymatic analysis, vol. 4, edited by Bergmeyer HV, Academic Press, New York, London, 1974, p1643-1647

11) Ohkawa H, Ohishi N, Yagi K : Assay for lipid peroxides in animal tissues by thiobarbituric acid reaction. Anal Biochem 95 : 351-358, 1979

12) Omura $T$, Sato $R$ : The carbon monoxidebinding pigment of liver microsomes. $\mathrm{J}$ Biol Chem 239 : 2370-2385, 1964

13) Lowry $\mathrm{OH}$, Rosenbrough $\mathrm{NJ}$, Farr $\mathrm{AL}$, et al: Protein measurement with the Folin phenol reagent. J Biol Chem 193: 265-275, 1951

14) Knodell RG, Holtzman JL, Crankshaw DL, et al : Drug metabolism by rat and human hepatic microsomes in response to interaction with $\mathrm{H}_{2}$-receptor antagonists. Gastroenterology $82: 84-88,1982$

15) Peterson FJ, Knodell RG, Lindemann NJ, et al : Prevention of acetaminophen and cocaine hepatotoxicity in mice by cimetidine treatment. Gastroenterology $35: 122-129,1983$

16) Yee NS, Shargel L: Effect of cimetidine or ranitidine pretreatment on hepatic mixed function oxidase activity in the rat. Drug Metab Dispos 14 : 580-584, 1986

17) Wilkinson $C F$, Hetnarski $K$, Yellin TO : Imidazole derivatives-A new class of microsomal enzyme inhibitors. Biochem Pharmacol 21: 3187-3192, 1972

18) Zimmerman $\mathrm{HJ}$ : Direct(toxipathic) hepatotoxins. In: Hepatotoxicity, edited by Zimmerman HJ, Appleton-Century-Crofts, New York, 1978, p198-219

19) Cluet JL, Boisset M, Boudene C: Effect of preteratment with cimetidine or phenobarbital on lipoperoxidation in carbon tetrachloride and tricholoroethylene-dosed rats. Toxicology 38 : 91-102, 1986

20) Poli G, Poli M, Slater TF : Effect of carbon tetrachloride on isolated rat liver cells : Stimulation of lipid peroxidation and inhibitory action of free-radical scavengers. Biochem Soc Transact $6: 589-591,1978$ 


\title{
Inhibition of carbon tetrachloride-induced liver injury by pretreatment with cimetidine
}

\author{
Fumio OKUno*, Yoichiro NAKano*, Masao ARAI**, Kazufumi SujITA*, Yoshiaki HIRANo*, \\ Sumiya ETO* and Hiromasa IsHIr***
}

This study was designed to investigate the effect of cimetidine on carbon tetrachloride $\left(\mathrm{CCl}_{4}\right)$ induced liver injury. A dose of $150 \mathrm{mg} / \mathrm{kg} \mathrm{BW}$ of cimetidine was pretreated 1 hour prior to $1.0 \mathrm{ml} / \mathrm{kg}$ BW $\mathrm{CCl}_{4}$ injection. Cimetidine significantly reduced increases in serum GOT and GPT, and ameliorated the histological findings by $\mathrm{CCl}_{4}$. Cimetidine inhibited increases in $\mathrm{MDA}$ in both blood and liver. Contents of hepatic cytochrome P-450 were preserved by cimetidine. These results indicate the important role of lipid peroxidation in the pathogenesis of $\mathrm{CCl}_{4}$ hepatotoxicity and cimetidine may exert the protective effect by inhibiting the lipid peroxidation at the level of cytochrome P-450.

* The First Department of Internal Medicine, University of Occupational and Environmental Health, UOEH (Kitakyushu)

** Central Clinical Laboratory, UOEH (Kitakyushu)

*** Department of Medicine, School of Medicine, Keio University (Tokyo) 